\section{Editorial}

Check for updates

\section{OPEN ACCESS}

Received: Oct 11, 2019

Accepted: Oct 15, 2019

Address for Correspondence:

Jin-Wook Kim, MD, PhD

Department of Medicine, Seoul National

University Bundang Hospital, 82 Gumi-ro

173 beon-gil, Bundang-gu, Seongnam 13620,

Republic of Korea

E-mail: kimjinw@snu.ac.kr

(C) 2019 The Korean Academy of Medical

Sciences.

This is an Open Access article distributed under the terms of the Creative Commons Attribution Non-Commercial License (https:// creativecommons.org/licenses/by-nc/4.0/) which permits unrestricted non-commercial use, distribution, and reproduction in any medium, provided the original work is properly cited.

ORCID iD

Jin-Wook Kim (iD)

https://orcid.org/0000-0003-0934-3344

Disclosure

The author has no potential conflicts of interest to disclose.

\title{
What is the Long-term Benefit of Direct-acting Antiviral Therapy in Chronic Hepatitis C?
}

\author{
Jin-Wook Kim (1D) ${ }^{1,2}$ \\ 'Department of Medicine, Seoul National University College of Medicine, Seoul, Korea \\ ${ }^{2}$ Department of Medicine, Seoul National University Bundang Hospital, Seongnam, Korea \\ - See the article "Durability of Sustained Virologic Response and Improvement of Fibrosis Markers after \\ Daclatasvir and Asunaprevir Treatment in Genotype 1b Hepatitis C Virus-Infected Patients: a Real Life \\ and Multicenter Study" in volume 34, number 41, e264.
}

Chronic hepatitis $\mathrm{C}(\mathrm{CHC})$ has become a curable disease with the advent of potent antiviral drug. Interferon-free regimens with direct-acting antivirals (DAAs) have not only reduced adverse drug reactions but also increased sustained virologic response (SVR) rates. The possibility of viral eradication is no longer an urgent clinical issue. Instead, the cost of DAA remains as a major barrier to the universal implementation of this magic bullet to all infected patients. Clinicians are challenged to make a decision whether their patients, especially stable ones despite long history of infection, will benefit from the antiviral therapy. This issue will be resolved with the longer follow-up studies with hard outcomes such as development of liver cancer and liver-associated mortality.

In this issue, Shin et al. ${ }^{1}$ showed from a real-world multicenter cohort that the daclatasvir/ asunaprevir combination induced durable SVR in CHC patients with genotype $1 \mathrm{~b}$ hepatitis $\mathrm{C}$ virus. More interestingly, the patients who had liver cirrhosis showed significant increase in biochemical markers of disease severity/fibrosis, along with improved liver stiffness measurement values. ${ }^{1}$ This finding is in line with previous reports demonstrating improvement of surrogate markers of fibrosis by antiviral treatment in CHC. ${ }^{2}$ Several points need to be considered, however, before embracing the all-too-good perspective. First, the duration of follow-up is not very long. Although exact medial follow-up time was not specified, the fact that about one-fourths of patients were still waiting for the 1-year assessment, long-term benefit on fibrosis markers has not been demonstrated against treatment-naïve CHC patients. Second, the non-invasive surrogate markers of fibrosis depend on inflammatory activity, therefore the improvement of fibrosis is overestimated. ${ }^{3}$ Moreover, the fact that the non-invasive markers reflect degree of fibrosis in treatment naïve $\mathrm{CHC}$ patients does not necessarily mean that these markers are also valid indicator of fibrosis reversal. Since repeated biopsy would not be practical in patients with good virologic response, other markers may be further sought such as hepatic venous pressure gradient (HVPG) which seems to be more reliable markers of fibrosis reversal.4,5 HVPG would be clinically appropriate too, considering that the improvement was demonstrated in cirrhotic patients only. ${ }^{1}$ Until more long-term data on hard outcomes are available, the SVR by DAA therapy may be regarded as a good augury rather than a promise fulfilled. 


\section{REFERENCES}

1. Shin SK, Lee JW, Ra H, Kwon OS, Shin JB, Jin YJ, et al. Durability of sustained virologic response and improvement of fibrosis markers after daclatasvir and asunaprevir treatment in genotype $1 \mathrm{~b}$ hepatitis $\mathrm{C}$ virus-infected patients: a real life and multicenter study. J Korean Med Sci 2019;34(41):e264. CROSSREF

2.. Singh S, Facciorusso A, Loomba R, Falck-Ytter YT. Magnitude and kinetics of decrease in liver stiffness after antiviral therapy in patients with chronic hepatitis C: a systematic review and meta-analysis. Clin Gastroenterol Hepatol 2018;16(1):27-38.e4.

3. Kardashian A, McKinney J, Huynh N, Yu R, Peters M, Catalli L, et al. Post-sustained virologic response liver stiffness may underestimate fibrosis after direct acting antiviral-containing therapy. Clin Infect Dis 2019;68(10):1784-7. PUBMED | CROSSREF

4. Lens S, Alvarado-Tapias E, Mariño Z, Londoño MC, LLop E, Martinez J, et al. Effects of all-oral anti-viral therapy on HVPG and systemic hemodynamics in patients with hepatitis C virus-associated cirrhosis. Gastroenterology 2017;153(5):1273-1283.e1. PUBMED | CROSSREF

5. Mandorfer M, Kozbial K, Schwabl P, Chromy D, Semmler G, Stättermayer AF, et al. Changes in HVPG predict hepatic decompensation in patients who achieved SVR to IFN-free therapy. Hepatology 2019. DOI: 10.1002/hep.30885.

PUBMED | CROSSREF 